УДК 128

DOI https://doi.org/10.32837/apfs.v0i27.923

Т. В. Яиула

ORCID ID: https://orcid.org/0000-0003-4686-4122

доктор педагогічних наук,

професор кафедри професійної освіти

Херсонського державного аграрно-економічного університету

\title{
ФІЛОСОФСЬКІ АСПЕКТИ РОЗУМІННЯ СМИСЛУ ЖИТТЯ В ПІДГОТОВЦІ МАЙБУТНЬОГО ПЕДАГОГА
}

Постановка проблеми у загальному вигляді. Проблема підвищення якості підготовки майбутніх педагогів пов'язана з розумінням свого місця в просторі життедіяльності людини, що навчається.

У сучасних соціокультурних умовах процес ідентифікації учня, студента відбувається на фоні не зовсім позитивних зразків середовища, що його оточує. Культ насильства, матеріальних цінностей, подвійної моралі стає тією основою, на якій формується ціннісна сфера особистості. Процес становлення педагога, здатного налагодити емоційно значущі зв'язки, включити учнів, студентів у свій світ цінностей, вимагає модернізації професійно-педагогічної підготовки. «Тільки особистістю педагога орієнтована освіта здатна стати особистісно орієнтованою освітою», - констатує В.I. Слободчиков [9].

Аналіз досліджень, публікацій. Смисложиттєві позиції особистості $є$ актуальною темою філософських, соціологічних, психологічних наукових пошуків. Питання осмислення життя знайшли відображення протягом розвитку філософської думки від Давньої Греції до сучасності. Особливе значення для нашого дослідження зазначена проблема мала через висвітлення ії у працях філософії екзистенціалізму (М. Хайдеггер, К.Ж. Ясперс, Ж.П. Сартр, А. Камю).

Філософія розглядала ії в трьох таких змістових аспектах:

1) нормативний як певна модель «належного» сенсу індивіда, що виводиться із загальних ідейних передумов тієї чи іншої філософсько-світоглядної системи, особливо з розуміння єства людини, з відповідних цьому єству форм самоздійснення людини у світі;

2) реальний як дійсне значення життя тієї чи іншої особи, об'єктивна спрямованість її життедіяльності;

3) суб'єктивний як усвідомлення конкретним індивідом смислу свого життя, що надає закінчена цільова освіта і з'ясування відповіді на питання, для чого живе людина [11, с. 134].

Мета статті полягає у розгляді смислу життя як важливого компоненту професійної підготовки майбутнього педагога.

Виклад основного матеріалу. Сьогодні навчання студентів у вищих закладах освіти орієнтовано на формування науково-предметних знань переважно через вербальну передачу інформації. Значна увага приділяється вивченню процесуальної сторони педагогічної діяльності. Проте, на наш погляд, залишається малорозробленим напрям активізації особистісного компонента в професійній підготовці майбутнього вчителя, педагога, викладача, актуалізації його як суб'єкта педагогічної дійсності і педагогічної діяльності.

Спираючись на принцип єдності свідомості й діяльності, відзначимо, що, з одного боку, діяльність обумовлює формування свідомості і самосвідомості, з іншого боку, свідомість є регулятором діяльності. Становлення людини як суб'єкта діяльності нерозривно пов'язано з розвитком самосвідомості. Тоді професійна свідомість учителя $€$ багаторівневим інтегральним психологічним утворенням, що слугує парадигмою, під кутом зору якої педагог сприймає, осмислює, оцінює отриману ззовні інформацію і здійснює свою діяльність.

Педагогічна свідомість містить систему взаємозалежних професійно-педагогічних цінностей, норм, ідеалів, свідомих і безсвідомих установок для себе як професіонала, оперативних знань про функціонування педагогічної системи та її елементів, програм педагогічних дій тощо.

Таким чином, для сучасного педагога важливо не тільки усвідомити структуру педагогічної діяльності, її основні компоненти, педагогічні дії, професійно важливі вміння і свої психологічні якості, але й «увійти» в простір педагогічної взаємодії на основі усвідомлення його сенсу у своєму саморозвитку, самовдосконаленні, самоактуалізації, а також у розвитку людини як смислоутворювального компонента свого життя.

Проблеми розвитку сенсу педагогічної діяльності сьогодні тільки починають набувати змістового наповнення в професійній підготовці майбутнього педагога (Р.X. Шакуров, В.Е. Чудновський, Т.В. Максимова).

Аналізуючи сприйняття педагогічної діяльності молодими вчителями (педагогами) з позиції їх смисложиттєвих орієнтацій, Т.В. Максимова фіксує досить низький його рівень. Так, наприклад, більшість молодих учителів не замислюється над проблемою сенсу життя і не пов'язує іï з власною 
професійною діяльністю. Для багатьох характерна нестійкість смисложиттєвих орієнтацій: розпочавши працювати в школі, вони ще не знайшли себе, не зробили остаточного професійного вибору, не відповіли на головне для себе питання про те, чому присвятити життя. Узагальнюючи дані, здобуті за різними методиками, автор виділяє такі три види (рівні) смислу життя.

1) «Ситуативний» сенс життя, що фактично зводиться до планування життя на найближчий період i не торкається основних особистісних установок і прагнень людини.

2) «Приземлений» життєвий сенс, що виявляється в орієнтуванні на елементарні матеріальні й духовні цінності (наявність певного авторитету в колективі, підвищення рівня матеріальної забезпеченості, сімейне благополуччя).

3) «Піднесений» сенс життя, що складається 3 максимальної творчої самореалізації, прагнення присвятити своє життя улюбленій справі, допомоги своїм вихованцям відшукати єдиний і неповторний для кожного життєвий смисл.

Розподіл респондентів за цим показником виявився таким: приблизно близько половини з них (48\%) мають «приземлений» смисл життя; $30 \%$ - «ситуативний», 22\% - «піднесений» смисл життя [7].

У контексті останнього Д.О. Леонтьєв зазначає, що життя будь-якої людини, оскільки воно на щось спрямоване, об'єктивно має сенс, що, однак, може не усвідомлюватися людиною до самої смерті. Водночас життєві ситуації можуть ставити перед людиною завдання щодо усвідомлення смислу ії життя [5, с. 47].

Отже, розвиток особистості пов'язаний із формуванням і розвитком їі ставлення до людей, світу, своєї діяльності, самої себе, що, зрештою, виявляється в усвідомленні свого призначення, смислу свого життя. Перетворення цих ставлень на стійкі і свідомо створювані, знаменує становлення людини як суб'єкта свого життя. Саме з такої позиції розглядає сучасна психологія категорію суб'єкта. «Людина як суб'єкт здатна змінювати власну життєдіяльність щодо практичного перетворення, ставитися до самої себе, оцінювати способи діяльності, контролювати ії хід і результати, змінювати її прийоми» [10, с. 250].

«Найважливішою характеристикою особистості як суб’єкта життєдіяльності, - відзначає К.О. Абульханова-Славська, - виступає знання, чого вона хоче, знання своїх об'єктивних можливостей, а головне, на що і як далеко вона піде заради своїх суспільних принципів» [1, с. 31].

Отже, значення життя й діяльності людини, їх усвідомлення є єдиним полем наукових пошуків. У цьому контексті В. Франкл зазначає, що в проблемі значення життя центральною є проблема відповідальності людини за своє життя [14, с. 29]. Відповідальна людина, на думку В. Франкла, - це людина, орієнтована на сенс і така, що прагне до цінностей [13, с. 245-252].

B.Е. Чудновський зазначає, що сенс життя може відігравати як конструктивну, так і деструктивну роль у формуванні особистості, тобто в цьому проявляється адекватність сенсу життя [15, с. 216]. У контексті проблеми нашого дослідження актуальною $є$ його думка про неадекватність сенсу життя в процесі професійного самовизначення. Професійні спрямування, що не враховують своєрідності індивідуальних особливостей і можливостей людини, сприяють формуванню неадекватного смислу життя, яке ніби закріплює ці прагнення, що призводить до життєвих конфліктів і негативно позначається на всьому процесі становлення особистості [15, с. 217]. Продовжуючи далі, В.Е. Чудновський виділяє такі характеристики адекватності сенсу життя:

1) реалістичність сенсу життя, тобто відповідність сенсу життя, з одного боку, наявним об'єктивним умовам, необхідним для його здійснення, з іншого боку, індивідуальним можливостям людини;

2) конструктивність сенсу життя - характеристика, що відбиває ступінь його позитивного або негативного впливу на процес становлення особистості та успішність діяльності людини [15, с. 217].

У процесі розгляду проблеми сенсу життя нами визначено та охарактеризовано його структурні компоненти, які в контексті розвитку професійно-педагогічної освіти мають динамічну характеристику. Це дає нам змогу проаналізувати напрями розвитку смисложиттєвих позицій майбутніх педагогів у ставленні до особистісної взаємодії з учнями, студентами задля їх особистісного розвитку. Аналізуючи зміст і структуру категорії сенсу життя, В.Е. Чудновський відзначає, що традиційно філософське трактування конфлікту між формою і змістом (стара форма відкидається як така, що не відповідає новому змісту) має не таку категоричну інтерпретацію: «зміни можуть нагромаджуватися саме в структурі, що поступово приводить до зміни змісту цілого» [15, с. 218]. Це пов'язано з тим, що людині властива наявність низки життєвих смислів. Автор виходить із того, що в основі структури сенсу життя лежить ієрархія смислів, співвідношення «великих" i «малих" смислів. «Особливості «структурної ієрархії» обумовлюють не тільки формально-динамічну, але й багато в чому змістовну характеристику цього феномена" [15, с. 218-219], тому становлення i функціонування сенсу життя як філософськопсихологічного феномена визначається не тільки змістом «головного смислу», але й характером його співвідношення з іншими життєвими сенсами. Отже, якщо один із компонентів сенсу життя, а саме цінність взаємодії педагога з особистістю людини (учня, студента), яка розвивається, набуває динамічної характеристики, то змінюється його ставлення до себе як значущої особистості, 
а сенс педагогічної діяльності стає співзвучним сенсу життя. Серед структур сенсу життя - «конгломерат» життєвих сенсів, монолітна структура, «авторитарна» ієрархія, «двополюсна» структура, «номінальна», "структура що розпадається», «ієрархія гармонійної взаємодії»- остання є найбільш адекватною як психічне новоутворення [15, с. 219-225]. В.Е. Чудновський пояснює це тим, що головний елемент ієрархії, будучи провідним, усе ж таки залишається елементом ієрархії. Динамічна взаємодія приводить до розвитку всіх елементів, а за певних умов і до зміни провідного компоненту. Так, наприклад, вибираючи професію вчителя, педагога, студент орієнтується на соціальний статус професії. Такий компонент доповнюється і збагачується цілою системою різноманітних сенсів, які він знаходить у процесі навчання у вищому навчальному закладі та завдяки аналізу соціокультурного середовища освіти. Цими сенсами можуть бути актуалізація творчого потенціалу, інтелектуально-ціннісна діяльність з оволодіння знаннями, уміннями, навичками, практико-орієнтуюче моделювання взаємодії тощо. Результатом стає або більш високий рівень усвідомлення соціального статусу педагога, тобто збагачений смисложиттєвий орієнтир у педагогічній діяльності, або заміна смисложиттєвого орієнтиру як ієрархічного компоненту на інші.

Взявши за основу розглянуті та охарактеризовані нами філософські, психолого-педагогічні орієнтири у визначенні смисложиттєвих положень, ми вважаємо, що під час професійно-педагогічної підготовки майбутніх педагогів, викладачів необхідно процес здобуття знань, умінь і навичок базувати на аналізі соціокультурної дійсності та життєдіяльності учнів, студентів, що дасть змогу розвивати особистісне ставлення до взаємодії як сенсу свого життя. Важливим компонентом у цьому процесі, як ми вважаємо, є рефлексивний аналіз власного життя в період дорослішання.

Об’єктивний сенс, що містить конкретні події, явища або поняття, може не збігатися з тим, що в них відкриває для себе індивід, тому що людина не просто актуалізує об'єктивний сенс тих чи інших подій та явищ, а одночасно фіксує своє суб'єктивне ставлення до них, пережите у формі особистісного сенсу.

Представляючи одне з головних утворень свідомості, особистісний сенс є індивідуалізованим відображенням дійсного ставлення особистості до об’єктів, заради яких розгортається її діяльність, усвідомлюваним як «значення для мене». У рамках теорії діяльності особистісний сенс визначається подвійно, а саме за способом походження (змістовно); за формою існування у свідомості (функціонально) [8, с. 438]. Це оцінка життєвого значення для суб'єкта об'єктивних обставин i його дій у цих обставинах.
Сенс мети дії і дії загалом, на нашу думку, залежить від того, якому мотиву воно слугує, задоволенню якої потреби воно сприяє. Якщо педагог особистісний сенс взаємодії вбачає в розвитку людини, у підтримці її становлення, то сенс професійної діяльності набуває гуманістичного характеру. Для особистості такого педагога зрозумілий сенс його життя, він збігається із сенсом педагогічної діяльності.

Д.О. Леонтьєв визначає динамічну значеннєву систему особистості як відносно стійку, автономну, ієрархічно організовану систему, що об'єднує низку різнорівневих значеннєвих структур i функціонує як єдине ціле. У значеннєвій сфері людини автор виділяє шість функціонально різних елементів, що належать до трьох рівнів організації [6, с. 129].

Перший рівень являють собою структури, безпосередньо включені в регуляцію процесів діяльності й психічного відображення, які відповідають особистісному змісту і значеннєвій установці.

Другий рівень - це рівень смислотвірних структур, участь яких у регуляторних процесах опосередковано породжуваними ними структурами першого рівня містить мотив, значеннєву диспозицію і значеннєвий конструкт.

Третій рівень (вищий) містить особистісні цінності, які визначаються автором як значеннєві конструкти, що є незмінними і стійкими в масштабі життя суб'єкта, джерелами смислотворення, автономії стосовно конкретних ситуацій взаємодії суб’єкта зі світом. Вони відрізняються трансситуативним характером і множинністю.

Розглядаючи взаємозв'язок цінностей та особистісного сенсу, В.В. Столін звертає увагу на зв'язок самосвідомості з мотиваційно-ціннісними структурами особистості. Він відзначає, що зріла, ефективна особистість має особливу якість мотивації, що полягає у співвідношенні діяльності окремої людини з людськими цінностями й зумовлює моральним смислом її існування [12].

Б.С. Братусь, аналізуючи смислову сферу особистості, також стверджує, що основою особистості є морально-ціннісна. Особистість - це «не спосіб здійснення позиції, а сама позиція людини в цьому складному світі, що задається системою загальних смислових утворень» [4, с. 128]. Крім цього, особистісні цінності розуміються ним як усвідомлені смислові утворення. «Цілісні системи смислових утворень задають не самі по собі конкретні мотиви, а площину відносин між ними, тобто саме той первісний план, ескіз майбутнього, що повинний передувати реальному втіленню» [3, с. 31].

3 огляду на це особистісний сенс педагогічної діяльності, на нашу думку, має отримати свою основу не в процесі педагогічної діяльності, а на етапі професійно-педагогічної підготовки. Цінності педагогічної діяльності, її особистісні сенси 
мотивують студентів під час навчання у вищих навчальних закладах на саморозвиток, самовдосконалення.

Особистість, як пише Б.С. Братусь, виявляється і формується через діяльність. При цьому суттєвою характеристикою цього поєднання є ціннісно-смислове ставлення до того, що відбувається [3, с. 123].

Визначаючи свою позицію в напрямі формування смислових утворень студентів вищих навчальних закладів, ми дотримуємося точки зору Б.С. Братуся, який розглядає такі функції смислових утворень як основних конституціональних одиниць свідомості.

1) Створення образу, ескізу майбутнього, тієї перспективи розвитку особистості, що не випливає прямо з наявної ситуації. На підставі цього ми стверджуємо, що проєктування майбутнім педагогом, викладачем можливої соціокультурної дійсності через аналіз сучасних обставин спонукає майбутніх педагогів до ціннісно-смислового самовизначення щодо взаємодії з людиною, що навчається.

2) Діяльність людини може оцінюватися й регулюватися з боку її успішності в досягненні тих чи інших цілей, її моральної оцінки. Цією опорою для людини стають смислові утворення, особливо у формі їхнього усвідомлення, а саме особистісних цінностей [3, с. 95-96]. Отже, особистісна взаємодія педагога з учнями, студентами, яка базується на знанні соціокультурних особливостей середовища їхнього життя, в процесуальному аспекті задовольняє потреби в повазі, безумовному прийнятті тощо, дає підстави для досягнення мети цієї взаємодії, якою є особистісний розвиток, що викликає у педагога, викладача відчуття успішності педагогічної діяльності, відповідно, її моральної оцінки, задоволення її смислом.

Майбутній педагог має бути особистістю, готовою до самореалізації в педагогічній діяльності, бачити в ній ціннісні сенси свого життя. Здобуття психолого-педагогічних знань, формування необхідних для педагогічної діяльності вмінь і навичок, за нашим висновком, необхідно поєднати 3 формуванням і розвитком смисложиттєвих орієнтацій студентів вищих навчальних закладів.

Завдяки усвідомленню сенсу педагогічної діяльності студентами вищих навчальних закладів сприймаються цінності, цілі, мотиви, функції взаємодії з людиною, що навчається. Знання, уміння, навички набувають статусу життєво необхідного потенціалу компетентності педагога.

3 аналізу зазначеного можна зробити висновок, що джерелами сенсів, які визначають, що для людини є значущим, а що ні й чому, яке місце ті чи інші об’єкти, явища посідають у її житті, є потреби та особистісні цінності людини. Як ті, так і інші посідають однакове місце в структурі мотивації людини та структурі породження смислів, адже смислу для людини набувають ті об'єкти, явища або дії, що стосуються реалізації якихось її потреб або особистісних цінностей [5, с. 38].

Висновки. Отже, сенс життя, сенс педагогічної діяльності пов'язаний з потребами людини, які є внутрішньою причиною їі активності, виступають мотивами дій. Мотив педагогічної дії є підставою для актуальної переваги саме педагогічної дії порівняно з іншими можливими об'єктами. Мотив базується на способі дії та одночасно формує образ результату. Саме цей образ досягнутого результату є метою педагогічної діяльності. Постановка мети - це механізм впливу індивіда на самого себе, свою активність, спосіб структурування майбутнього.

Отже, у процесі підготовки майбутніх педагогів необхідним є насамперед формування здатності ставити власну мету педагогічної діяльності, аналізувати її не тільки як таку, але й як шлях iї досягнення. Тоді аналіз цих шляхів сприятиме уточненню поставленої особистістю мети. Мотив діяльності, цілепокладання стає основою установки на досягнення певного результату. Образ результату може перебувати в декількох станах, таких як знаний, привабливий, реально досяжний, досягнутий.

Під цим кутом зору сенс педагогічної діяльності набуває якісної характеристики значущості мети. За цих умов значущість педагогічної взаємодії переноситься на все, що виявляється з нею пов'язаним. Таким чином, формуючи в майбутніх педагогів сенс педагогічної діяльності, педагогічної взаємодії, ми розвиваємо ціннісну сферу майбутнього педагога у сприйнятті світу педагогічної дійсності. Процес поширення значущості відбувається послідовно від одного об’єкта до іншого за обов'язкової умови наявності зв'язку між ними. У результаті цього виникають ланцюжки сенсу, а саме ланцюжки поширення значущості. Ланцюжок смислів - це відповіді на вічні питання діяльності людини «Навіщо?», «Чому?», «Для чого?» тощо.

Отже, можемо констатувати, що поняття «сенс» є наявністю в об’єкта, процесу, явища міри конкретного індивідуально значущого. Сенс можна зрозуміти або не зрозуміти, погодитися з ним або не погодитися. Однак сенс ще можна прийняти, саме прийняття сенсу спрямовує дії людини на досягнення певної мети. Тоді втрата сенсу педагогічної діяльності - це низька оцінка її значущості, тому під час вирішення проблеми формування смисложиттєвих орієнтацій майбутніх педагогів необхідно, на нашу думку, насамперед вирішити питання значущості педагога, викладача в соціумі, культурі, житті кожної людини. 


\section{Jimepamypa}

1. Абульханова-Славская К.А. Развитие личности в процессе жизнедеятельности. Психология формирования и развития личности. Москва, 1981. С. 19-45.

2. Бондаревская Е.В., Кульневич С.В. Парадигмальный подход к разработке содержания ключевых педагогических компетенций. Педагогика. 2004. № 10 . C. $23-31$.

3. Братусь Б.С. Аномалии личности. Москва : Мысль, 1988. 301 с.

4. Братусь Б.С. Психологические аспекты нравственного развития личности. Москва : Знание, 1977. 64 с. (Новое в жизни, науке, технике: Серия «Этика», № 6).

5. Леонтьев Д.А. Очерк психологии личности. 2-е изд. Москва : Смысл, 1997. 64 с.

6. Леонтьев Д.А. Психология смысла: природа, строение и динамика смысловой реальности. Москва : Смысл, 2003. 487 с.

7. Максимова Т.В. Смысл жизни и индивидуальный стиль педагогической деятельности. Мир психологии. 2001. № 2. С. 114-118.

8. Психологический словарь / авт.-сост. В.Н. Копорулина, М.Н. Смирнова, Н.О. Гордеева, Л.М. Балабанова ; под общ. ред. Ю.Л. Неймера. Ростов-на-Дону : Феникс, 2003. 640 с.

9. Слободчиков В.И. Психологические основы личностно ориентированного образования. Відкритий урок. 2004. № 21-24. С. 26-30.

10. Слободчиков В.И., Исаев Е.И. Основы психологической антропологии. Психология человека. Введение з психологию субъективности : учебное пособие для студентов высших педагогических учебных заведений. Москва : Школа-пресс, 1995. 383 с.

11. Сохань Л.В., Тихонович В.А. Стиль жизни личности: теоретические и методологические проблемы. Киев : Научная мысль, 1982. 372 с.

12. Столин В.В. Самосознание личности. Москва : МГУ, 1983. $286 \mathrm{c.}$

13. Франкл В. Духовность, свобода, ответственность. Психология личности в трудах зарубежных психологов / сост. и общ. ред. А.А. Реана. Санкт-Петербург : Питер, 2000. 320 c.

14. Франкл В. Человек в поисках смысла / пер. с нем. и англ. ; общ. ред. Л.Я. Гозмана, Д.А. Леонтъева. Москва : Прогресс, 1990. 368 с.

15. Чудновский В.Э. Становление личности и проблема смысла жизни. Избранные труды. Москва : издательство Московского психолого-социального института ; Воронеж : изд. НПО «МОДЭК», 2006. 768 с.

\section{Анотація}

Яиула Т. В. Філософські аспекти розуміння смислу життя в підготовці майбутнього педагога. - Стаття.

У статті розглянуто філософські та психологічні аспекти розвитку смисложиттєвої позиції педагога. Автором обгрунтовано важливість розвитку в педагогів сприйняття педагогічної діяльності як смисложиттєвої цінності власного життя. Для сучасного педагога важливо не тільки усвідомити структуру педагогічної діяльності, їі основні компоненти, педагогічні дії, професійно важливі вміння і свої психологічні якості, але й «увійти» в простір педагогічної взаємодії на основі усвідомлення його сенсу у своєму саморозвитку, самовдосконаленні, самоактуалізації та у розвитку людини як смислоутворювального компонента свого життя. Завдяки усвідомленню сенсу педагогічної діяльності студентами закладів вищої освіти сприймаються цінності, цілі, мотиви, функції взаємодії з людиною, яка навчається. Знання, уміння, навички набувають статусу життєво необхідного потенціалу компетентності педагога.

Сенс мети дії та дії загалом залежить від того, якому мотиву вона слугує, задоволенню якої потреби сприяє. Якщо педагог особистісний сенс педагогічної діяльності, взаємодії вбачає в розвитку людини, підтримці їі становлення, то й сенс професійної діяльності набуває гуманістичного характеру. Для особистості такого педагога зрозумілий сенс його життя, він збігається із сенсом педагогічної діяльності.

Представляючи одне з головних утворень свідомості, особистісний сенс є індивідуалізованим відображенням дійсного ставлення особистості до об'єктів, заради яких розгортається їі діяльність, усвідомлюваним як «значення для мене».

Цінності педагогічної діяльності, її особистісні сенси мотивують студентів під час навчання у закладах вищої освіти на саморозвиток, самовдосконалення.

Процес поширення значущості змісту навчання відбувається послідовно від одного об'єкта до іншого за обов'язкової умови наявності зв'язку між ними. У результаті цього виникають ланцюжки сенсу, а саме ланцюжки поширення значущості. Ланцюжок смислів - це відповіді на вічні питання діяльності людини «Навіщо?», «Чому?, «Для чого?» тощо.

Освітній процес у закладі вищої освіти має бути насичений особистісно розвивальними засобами, які б дали змогу майбутньому педагогові орієнтуватись у смислах взаємодії зі школярами, студентами, смислах педагогічної діяльності як смислоутворювального складника сенсу власного життя.

Ключові слова: сенс життя, сенс педагогічної діяльності, цінності взаємодії з учнем, студентом, смисложиттєвий орієнтир у педагогічній діяльності.

\section{Summary}

Yatsula T. V. Philosophical aspects of understanding the sense of life in the training of future teachers. - Article.

The article considers the philosophical and psychological aspects of the development of the life-sense position of the teacher. The author substantiates the importance of developing teachers' perception of pedagogical activity as the life-sense value of their own lives. It is important for a modern teacher to understand not only the structure of pedagogical activity, its main components, pedagogical actions, professionally important skills and their psychological qualities, but also to "enter" the space of pedagogical interaction based on awareness of its meaning in self-development, self-improvement, self-actualization and development of a person as a meaning-forming component of their life. Due to the awareness of the meaning of pedagogical activity, students of higher education institutions perceive the values, goals, motives, functions of interaction with the person who is studying. Knowledge, skills, abilities acquire the status of vital potential of the teacher's competence.

The meaning of the purpose of action and action in general, depends on what motive it serves the satisfaction 
of which it contributes. If the teacher sees the personal meaning of pedagogical activity, interaction in human development, in support of its formation, then the meaning of professional activity acquires a humanistic sense. For the personality of such a teacher, the sense of their life is clear; it coincides with the meaning of pedagogical activity.

Representing one of the main formations of consciousness, personal meaning is an individualized reflection of the true attitude of the individual to the objects for which their activity unfolds, perceived as "sense to me".

The values of pedagogical activity, its personal meanings motivate students during their studies in higher education institutions for self-development and self-improvement.
The process of spreading the importance of learning content takes place sequentially from one object to another, provided that there is a connection between them. As a result, there are chains of meaning - chains of distribution of significance. The chain of meanings is the answers to the eternal questions for human activity "Why?", "For what?" etc.

The educational process in a higher education institution should be saturated with personal development tools that would allow the future teacher to navigate in terms of interaction with students, the meaning of teaching as a meaningful component of the sense of their own lives.

Key words: sense of life, meaning of pedagogical activity, values of interaction with the school/university students, life-sense concept in pedagogical activity. 